\title{
Characterization and biological activity of condensed tannins from tropical forage legumes
}

\author{
Tatiana Pires Pereira(1), Elisa Cristina Modesto(1), Delci de Deus Nepomuceno(2), Osniel Faria de Oliveira(3), \\ Rafaela Scalise Xavier de Freitas ${ }^{(1)}$, James Pierre Muir( ${ }^{(4)}$, José Carlos Batista Dubeux Junior ${ }^{(5)}$ \\ and João Carlos de Carvalho Almeida(1)
}

\begin{abstract}
(1)Universidade Federal Rural do Rio de Janeiro, Rodovia BR-465, Km 07, s/no, Zona Rural, CEP 23890-000 Seropédica, RJ, Brazil. E-mail: tpireszootec@gmail.com, ecmodesto@gmail.com, rafascalise@hotmail.com, joaocarlosbq@gmail.com (2)In memoriam (3)Universidade Federal Rural de Pernambuco, Dois Irmãos, CEP 52171-900 Recife, PE, Brazil. E-mail: niel_zoo@hotmail.com ${ }^{(4)}$ Texas AgriLife Research and Extension Center, Stephenville, TX, USA. E-mail: j-muir@tamu.edu ${ }^{(5)}$ University of Florida, North Florida Research and Education Center, Highway, Marianna, FL, USA. E-mail: dubeux@ufl.edu
\end{abstract}

\begin{abstract}
The objective of this work was to characterize condensed tannins (CT) from six tropical forage legumes and to determine their biological activity. The monomers propelargonidin, prodelphinidin and procyanidin were analyzed, as well as extractable condensed tannin (ECT), protein-bound CT (PBCT) and fiber-bound CT (FBCT), molecular weight, degree of polymerization, polydispersity index, and biological activity by protein precipitate by phenols (PPP) of leaves of the legumes Cajanus cajan, Gliricidia sepium, Stylosanthes capitata x Stylosanthes macrocephala (stylo), Flemingia macrophylla, Cratylia argentea, and Mimosa caesalpiniifolia, and of the bark of this latter species. Differences were observed in the concentrations of ECT, PBCT, PPP, and total condensed tannin among species, but not in that of FBCT. The highest value of PBCT occurred in F. macrophylla. Total CT varied from nondetected concentration in C. argentea to the highest concentration in M. caesalpiniifolia leaves that contain the greatest levels of PPP. No differences were observed for polymerization degree in stylo, F. macrophylla, and M. caesalpiniifolia. Leaves of stylo, C. cajan, and G. sepium, all containing between 20 and $50 \mathrm{~g} \mathrm{~kg}^{-1}$ total CT, should be beneficial CT sources, if offered as sole feeds in ruminant diets. The ratio of prodelphinidin:procyanidin varies from 10:80 (stylo) to 65:35 (F. machrophylla), and propelargonidin is only determined in C. argentea.
\end{abstract}

Index terms: forage legumes, phenols, procyanidins, prodelphinidins, protein.

\section{Caracterização e atividade biológica de taninos condensados de leguminosas forrageiras tropicais}

Resumo - O objetivo deste trabalho foi caracterizar taninos condensados de seis leguminosas forrageiras e determinar sua atividade biológica. Os monômeros propelargonidina, prodelfinidina e procianidina foram analisados, assim como taninos condensados extraíveis (TCE), taninos condensados ligados a proteínas (TCLP) e ligados a fibras (TCLF), massa molecular, grau de polimerização, índice de polidispersão e atividade biológica, por meio de proteínas precipitadas por fenóis (PPF), em folhas das leguminosas Cajanus cajan, Gliricidia sepium, Stylosanthes capitata x Stylosanthes macrocephala (estilosantes), Flemingia macrophylla, Cratylia argentea e Mimosa caesalpiniifolia, e na casca desta última espécie. Foram observadas diferenças nas concentrações de TCE, TCLP, PPF e total de taninos condensados entre as espécies, mas não na de TCLF. O maior valor de TCLP ocorreu em $F$. macrophylla. O total de TC variou de não detectável em $C$. argentea à maior concentração em folhas de $M$. caesalpiniifolia, que contêm os maiores níveis de PPF. Não se observaram diferenças quanto ao grau de polimerização em estilosantes, $F$. macrophylla e M. caesalpiniifolia. Folhas de estilosantes, C. cajan e G. sepium, todas com total de TC entre 20 e $50 \mathrm{~g} \mathrm{~kg}^{-1}$, poderiam ser fontes benéficas de TC, se oferecidas como única fonte de alimentos em dietas de ruminantes. A proporção prodelfinidina:procianidina variou de 10:80 (stylo) a 65:35 (F. machrophylla), e a propelargonidina é determinada somente em $C$. argentea.

Termos para indexação: leguminosas forrageiras, fenóis, procianidina, prodelfinidina, proteínas.

\section{Introduction}

The shortage of great quality forage and livestock feed resources is a limitation for ruminant production in some developing countries. The wider use of herbaceous, shrubby, and arboreal legumes intercropped with grasses, or as a protein pool, may
Pesq. agropec. bras., Brasília, v.53, n.9, p.1070-1077, Sept. 2018 DOI: 10.1590/S0100-204X2018000900011 (cc) By This is an open-access article distributed under the Creative Commons Attribution 4.0 International License 
provide a solution (Muir et al., 2014), as these plants can improve ruminant nutrition because of their great protein amount and digestibility, which improves grass digestibility in the rumen. Legumes can also serve as a food reserve for dry seasons or drought years, besides supplying nitrogen to the pasture ecosystem, thereby decreasing the dependence on expensive fertilizers, in comparison to grass monoculture (Nepomuceno et al., 2013).

Many tropical legumes have low palatability to ruminants during the rainy season (Andersson et al., 2006). Thus, the greatest effect of low palatability legumes often occurs in transition from rainy to dry seasons when environmental conditions for grass growth and quality limit ruminant intake. Acceptability of tropical forage legumes is often related to the presence of secondary metabolic compounds such as tannins, saponins, terpenes and lignin, compounds designated as "anti-nutritional factors" when they reduce the consumption or feed nutritional value (Nepomuceno et al., 2013). They interfere with digestibility, nutrient uptake or utilization, and, if ingested in high concentrations, can harm ruminant health (Lamy et al., 2011).

Condensed tannins are phenolic compounds classified as flavan-3-ol polymers with widely differing molecular weights (Mueller-Harvey, 2006). They are often present in tropical legumes, and act as chemical defense mechanisms against pathogens, insects, and herbivores (Terril et al., 1992). Their ability to bind with proteins and other macromolecules, which is reversible at acid $\mathrm{pH}$ (Dentinho \& Bessa, 2016), allows them to play important roles in ruminant nutrition by increase plant amino acid absorption in small intestine (protein bypass). They also can reduce gastro-intestinal parasites, and mitigate rumen methanogenesis, which improves energy efficiency, and alter the nitrogen elimination route from urine to feces, providing less negative effects on the environment (Naumann et al., 2014).

Due to the highly heterogeneous phenolic chemical structures in legumes (Mueller-Harvey, 2006), condensed tannins from different plant species may cause different responses to the availability of nutrients and their use by ruminants, even when consumed at the same concentration (Dentinho \& Bessa, 2016). However, Guimarães-Beelen et al. (2006) reported that one of the factors that promote this difference in biological activity among plants is the greatest concentration of the prodelphinidin monomer, which promotes a greater biological activity and astringency due to its greater hydroxyl radicals in the structure.

There are different methods to evaluate the condensed tannins amount and their biological activity. Most quick colorimetric methods provide little information on biological activity (Mueller-Harvey, 2006). Gea et al. (2011) suggested the use of highperformance liquid chromatography to determine the degree of polymerization, prodelphinidin:procyanidin ratio and molecular weight. Although these procedures are laborious and costly, they can reliably determine the condensed tannins activities of forage legumes for ruminant feed. A range of effects of different plants on ruminant nutrition and health are caused by different types and quantities of condensed tannins (Naumann et al., 2014).

The objective of this work was to characterize condensed tannins from six tropical forage legumes and determine their biological activities.

\section{Materials and Methods}

Approximately $2 \mathrm{~kg}$ of leaf dry matter (DM), of each of the species - Cajanus cajan, Gliricidia sepium, Stylosanthes capitata x S. macrocephala (stylo), Flemingia macrophylla, Cratylia argentea, Mimosa caesalpiniifolia -, as well as the bark of the latter species, and branches with up to $12 \mathrm{~cm}$ diameter, were collected at different maturity stages, in the experimental area of Embrapa Agrobiologia, in the municipality of Seropédica, state of Rio de Janeiro, Brazil, in October and November 2013. The material was dried in a ventilated hangar with average $28^{\circ} \mathrm{C}$, for one week. A representative $100 \mathrm{~g}$ subsample was ground using a hammer mill fitted with a $1 \mathrm{~mm}$ sieve, and shipped to Texas A\&M AgriLife Research in Stephenville, Texas, USA, for CT analysis.

Purification of condensed tannins (CT) from each legume species was performed according to Wolfe et al. (2008), by extracting them from plant tissues (25 g). Purified CT from each species was used to develop specific patterns, as well as to determine their molecular weight (Mw) and monomers. Proteins precipitated by phenols (PPP) were analyzed from plant crude extracts $(50 \mathrm{mg}$ ) in duplicate, as described by Hagerman \& Butler (1978), and were well-correlated

Pesq. agropec. bras., Brasília, v.53, n.9, p.1070-1077, Sept. 2018 DOI: $10.1590 / \mathrm{S} 0100-204 X 2018000900011$ 
with biologically active CT on animals. Crude extract was used due to limitations of the purified CT amount.

Fractions of CT were determined as described by Terrill et al. (1992), from which extractable condensed tannin (ECT) was determined with $10 \mathrm{~mL}$ of acetone:water solution (70:30) followed by $10 \mathrm{~mL}$ of diethyl ether. Fraction of protein-bound CT (PBCT) were extracted from ECT residue with $10 \mathrm{~mL}$ of sodium dodecyl sulfate-mercaptoethanol containing $0.01 \mathrm{~mol} \mathrm{~L}^{-1}$ Tris-HCl. The fiber-bound CT (FBCT) was determined using the residue after ECT and PBCT analysis. Those fractions were determined based on absorbance at $550 \mathrm{~nm}$, in sequence with butanol- $\mathrm{HCl}$ reaction $(5 \% \mathrm{v} / \mathrm{v} \mathrm{HCl})$. The dried phenolic-protein residue was analyzed for nitrogen $(\mathrm{N})$ using Vario Macro Elementary C:N (Elementary Americas, Inc., Mt. Laurel, NJ, USA). Nitrogen percentage was multiplied by 6.25 to estimate crude protein.

The CT molecular mass was determined using a gel permeation chromatography attached to the highperformance liquid chromatography (HPLC) modular system according to Huang et al. (2010). Molecular weights were calculated based on the calibration curve established with polystyrene low Easi vials standards (Agilent Technologies, Santa Clara, CA, USA), with Mw ranging from 162 to $38,640 \mathrm{Da}$. The weightaverage molecular weight $(\mathrm{Mw})$ and number-average molecular weight $(\mathrm{Mn})$ were integrated and quantified by Breeze software (Knoll Road, Camberley, Surrey GU15 3SY, UK). Degree of polymerization is the estimated number of monomers that make up the purified CT polymer, according to Williams et al. (1983), in which a single unit of proanthocyanidin has approximately $500 \mathrm{Da}$ of $\mathrm{Mw}$, while the polydispersity index represents the molecular weight distance distributed in the polymer, and it was assessed using the equation $\mathrm{Mw} / \mathrm{Mn}$.

We determined the prodelphinidin:procyanidin ratio of CT from six plants, using anthocyanidin monomers as described by Naumann et al. (2015), using purified CT added to butanol acid. Delphinidin and propelargonidin (Sigma-Aldrich Co., St. Louis, MO, USA) were used as standards in HPLC- controlled by Breeze software.

The experimental design was completely randomized with seven treatments (leaves from six species plus $M$. caesalpiniifolia bark) replicated four times. Dependent variables included the percentages of ECT, PBCT, FBCT, and TCT, and the structural characteristics included properlargonidin, prodelphinidin, and procyanidin, the degree of polymerization, polydispersity index, Mw, Mn, PPP, and PB. Data were subjected to analysis of variance and Tukey's test mean using the RStudio software (250 Northern Ave, Boston, MA 02210). Differences were considered significant at 5\% probability.

\section{Results and Discussion}

Concentrations of ECT, PBCT, TCT, and PPP differed among species $(p<0.05)$. No differences were found for FBCT in none of the studied legumes (Table 1). The ECT fraction is the largest TCT component in tropical legumes (Terril et al., 1992). ECT fraction ranged from nondetected in $C$. argentea and $G$. sepium up to $79 \mathrm{~g} \mathrm{~kg}^{-1}$ in sabiá leaves, which is significantly greater than the values found in F. macrophylla, C. cajan, and $M$. caesalpiniifolia bark - 41, 25, and $15 \mathrm{~g} \mathrm{~kg}^{-1}$, respectively.

The PBCT concentration was the highest in F. macrophylla $\left(53 \mathrm{~g} \mathrm{~kg}^{-1}\right)$, at $5 \%$ probability.

The TCT concentration ranged from nondetected ones (C. argentea) to $124 \mathrm{~g} \mathrm{~kg}^{-1}$ in M. caesalpiniifolia leaves, which was greater than the TCT concentration found in the other legumes and in M. caesalpiniifolia bark $(\mathrm{p}<0.05)$, showing differences in this compound among the studied species and plant fractions within the same species (Veteli et al., 2007).

The legumes in our study had widely differing PPP concentrations $(p<0.05)$, and M. caesalpiniifolia leaves showed the greatest PPP content. The PPP amount was similar in C. cajan and F. macrophylla, and greater than those of stylo leaves and M. caesalpiniifolia bark. The species $C$. argentea and G. sepium had no PPP.

Stürm etal. (2007) observed CT values in C. argentea and $F$. macrophylla similar to those reported in our study. Their results for F. macrophylla were $5 \%$ of ECT, but TCT was lower (5\%), and no FBCT and PBCT were observed. Cano et al. (1994) studied the biological activity of $\mathrm{CT}$ in tropical legumes, and reported $79 \%$ of ETC, $14 \%$ of PBCT, and $7 \%$ of FBCT. The values of ECT, PBCT and FBCT were greater than those found in our study; however, these authors did not report the percentage of FBCT.

Balogun et al. (1998) reported only traces of ECT in Gliricidia $(<1 \%)$, but $2 \%$ PBCT and $4 \%$ TCT, which 
are similar values to those found in the present study. However, Lara et al. (2000) reported for Gliricidia $4 \mathrm{~g} \mathrm{~kg}^{-1}$ of ECT, $30 \mathrm{~g} \mathrm{~kg}^{-1}$ of PBCT, $5 \mathrm{~g} \mathrm{~kg}^{-1}$ of FBCT, and $40 \mathrm{~g} \mathrm{~kg}^{-1}$ of TCT. Nozella (2001) evaluated tannin concentrations in plants with forage potential for ruminants, and reported that Gliricidia had low levels of phenols (13.72 $\left.\mathrm{g} \mathrm{kg}^{-1} \mathrm{DM}\right)$, tannins (6.86 $\left.\mathrm{g} \mathrm{kg}^{-1} \mathrm{DM}\right)$, and CT $\left(0.3 \mathrm{~g} \mathrm{~kg}^{-1} \mathrm{DM}\right)$.

Optimum performance is often observed in ruminants fed diets containing moderate CT levels - from 20 to $50 \mathrm{~g} \mathrm{~kg}^{-1}$ (Animut et al., 2008; Muir, 2011). Benefits normally derive from the plant protein protection from microbial degradation in the rumen (by-pass), with a corresponding increase of absorption of plant amino acids in the gut, improved animal performance results (Patra \& Saxena, 2011), and anthelmintic effect (Iqbal et al., 2002).

Even though, forage legumes without CT are a good source of protein, since they serve as an input of $\mathrm{N}$ to ruminants, representing a possible alternative to more expensive dietary inputs, especially when feed quality is limiting (Muir et al., 2014). Leaves of stylo, C. cajan, and G. sepium, all of which contained between 20 and $50 \mathrm{~g} \mathrm{~kg}^{-1} \mathrm{TCT}$, if offered as sole feeds in ruminant diets, should be beneficial CT sources (Table 1). According to Gonçalves et al. (2010), M. caesalpiniifolia bark has potential as a source of CT. Although the bark is not considered as forage, it was included in the present study because it might be used as a potential tannin additive to ruminant diets, to enhance livestock performance (Sartor Neto et al., 2011).
Diets containing more than $50 \mathrm{~g} \mathrm{CT} \mathrm{kg}^{-1} \mathrm{DM}$ may negatively affect the feed intake and digestibility. Therefore, high-CT legumes, such as M.caesalpiniifolia and $F$. macrophylla, should be offered with other forages containing no CT (Littlefield et al., 2011). For instance, lambs fed quebracho (Schinopsis spp.) extract in diets containing $89 \mathrm{~g} \mathrm{CT} \mathrm{kg}^{-1} \mathrm{DM}$ had reduced DM intake of fresh vetch (Vicia sativa), in comparison to lambs fed the same forage without CT (768 vs. $956 \mathrm{~g}$ per day) (Patra \& Saxena, 2011). The tannin content found in our study for the sabiá was $12 \%$, which is lower than that found (17\%) by Guimarães-Beelen et al. (2006), who reported that CT contents greater than $10 \%$ on DM basis may have detrimental effect on ruminants. Lamy et al. (2011) mentioned that certain herbivores, such as goats, can secrete proline and other salivary proteins as a mechanism of temporary CT inactivation. However, in vitro analyses, followed by in vivo trials, should confirm such assertions because the biological activity of a specific legume CT can vary.

According to Lin et al. (2007), the changes in CT structure probably causes a decrease of the protein binding capacity. Low-PPP values in mature and senescing plants may result from an increasing degree of polymerization and reduced active sites on CT molecules, resulting in less likelihood of complexation with proteins. Guimarães-Beleen et al. (2006) confirmed that CT variation can occur at different stages of phenological cycle of plants. This may or may not have been a factor in our study because the age of the species was not evaluated.

Table 1. Concentration of extractable condensed tannin (ECT), protein-bound condensed tannin (PBCT), fiber-bound condensed tannin (FBCT), and total condensed tannin (TCT), as well as protein precipitaded by phenols (PPP), in leaf dry matter of six tropical forage legumes ${ }^{(1)}$.

\begin{tabular}{|c|c|c|c|c|c|}
\hline \multirow[t]{2}{*}{ Legume } & ECT & PBCT & FBCT & TCT & PPP \\
\hline & $-----\cdot$ & & $\left(\mathrm{g} \mathrm{kg}^{-1}\right)$ & 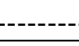 & $---\cdot-$ \\
\hline Cratylia argentea & ND & 1e & ND & ND & ND \\
\hline Stylosanthes capitata $\times$ S. macrocephala & $9 \mathrm{e}$ & $14 d$ & ND & $23 \mathrm{e}$ & $03 \mathrm{~d}$ \\
\hline Flemingia macrophylla & $41 b$ & $53 \mathrm{a}$ & ND & $93 b$ & $42 b$ \\
\hline Gliricidia sepium & ND & $35 \mathrm{c}$ & ND & $36 \mathrm{~d}$ & ND \\
\hline Cajanus cajan & $25 \mathrm{c}$ & $8 \mathrm{~d}$ & ND & $33 \mathrm{~d}$ & $37 \mathrm{~b}$ \\
\hline Mimosa caesalpiniifolia (leaf) & $79 \mathrm{a}$ & $44 \mathrm{~b}$ & ND & $124 \mathrm{a}$ & $160 \mathrm{a}$ \\
\hline M. caesalpiniifolia (bark) & $15 \mathrm{~d}$ & $35 \mathrm{c}$ & ND & $50 \mathrm{c}$ & $11 \mathrm{c}$ \\
\hline Coefficient of variation (\%) & 5.7 & 7.6 & - & 8.1 & 6.5 \\
\hline
\end{tabular}

(1)Means followed by equal letters, in the columns, do not differ, by Tukey's test, at $5 \%$ probability. ND, nondetected. Results presented on a dry matter basis, and standard curves based on purified condensed tannins from each species. 
Terrill et al. (1994) showed that increases of sampledrying temperature decreased ECT from Calliandra calothyrsus and Lespedeza cuneata and increased PBCT and FBCT fractions. According to Muetzel \& Becker (2006), drying in a greenhouse did not negatively affect the extraction and biological activity of CT, but decreased the solubility of cell wall and protein, reducing its degradability in the rumen. Lin et al. (2007) studied different plant fractions and phenological stages, and found that CT fractions, TCT, and PPP decreased as plant maturity advanced. The PPP determines the amount of bioactive condensed tannins of interest in ruminant nutrition (Cooper et al., 2014), however, the extent of the bioactivity depends on other factors such as tannin structure and concentration, physical status of the animal, and diet-related factors such as protein concentration (Naumann et al., 2014).

The degree of polymerization (DP), the polydispersity index (PDI), Mw, and Mn varied among species (Table 2). No differences were observed for DP between stylo, F. macrophylla, and M. caesalpiniifolia bark; however, DP values of these plants were greater than the ones observed for $C$. argentea, G. sepium, C. cajan, and M. caesalpiniifolia leaves, with no differences found within this last group of legumes. The PDI in decreasing order occurred in M. caesalpiniifolia (both bark and leaves), C. cajan, C. argentea, stylo, F. macrophylla, and G. sepium.

Stylo showed the greatest $\mathrm{Mw}(1,168 \mathrm{Da})$, and $G$. sepium, the lowest $\mathrm{Mw}(737 \mathrm{Da})$, whereas F. macrophylla, M. caesalpiniifolia (bark and leaves), $C$. cajan, and $C$. argentea showed, in a decreasing order, intermediate values, respectively (Table 2).
No differences were found for $\mathrm{Mw}$ between $F$. macrophylla and M. caesalpiniifolia bark, and between Mimosa leaves and C. cajan. Stylo, F. macrophylla, $M$. caesalpiniifolia, $C$. argentea, $C$. cajan, and $G$. sepium showed decreasing values for $\mathrm{Mw}$, respectively. No differences were observed for $\mathrm{Mn}$ between $M$. caesalpiniifolia fractions, and between C. argentea and C. cajan.

The Mw of CT ranged from 500 to more than 20,000 Da (Mane et al., 2007), the concentration as well as the chemical structure were determinants of their biological activity (Guimarães-Beelen et al., 2006). Naumann et al. (2014) found weak correlations between the Mw of legume CT and PPP. According to Cano et al. (1994), CT ability to bind and precipitate proteins increases as the degree of polymerization and Mw increases. Huang et al. (2010) worked with Leucaena hybrids and found that CT Mw ranged from 2,737 to $2,871 \mathrm{Da}$, but the authors could not attribute $\mathrm{CT}$ binding affinity to proteins directly to $\mathrm{Mw}$ because, according to them, the chemical structure can also play a vital role in this feature. In the case of the legumes we studied, stylo CT had low-PPP concentration (Table 1), but high-Mw value (Table 2), which was not the case for F. macrophylla or C. cajan.

Naumann et al. (2014) evaluated perennial legumes from warm climates in Southern North America, and found ECT Mw ranging from 552 to 1,483 $\mathrm{Da}$, values that are close to those found in our study (Table 2). These authors found that Mw did not, however, explain biological activity as measured by in vitro rumen methanogenesis, suggesting the need for further research on $\mathrm{Mw}$ in PBCT and FBCT. Other factors,

Table 2. Degree of polymerization (DP), polydispersity index (PDI), relative weight-average molecular weight (Mw), and number-average molecular weight $(\mathrm{Mn})$, for six tropical forage legumes ${ }^{(1)}$.

\begin{tabular}{|c|c|c|c|c|}
\hline Legume & $\mathrm{DP}$ & PDI & $\mathrm{Mw}(\mathrm{Da})$ & $\mathrm{Mn}$ \\
\hline Cratylia argentea & $1.6 \mathrm{~b}$ & $2.9 \mathrm{c}$ & $791 \mathrm{~d}$ & $274 d$ \\
\hline Stylosanthes capitata $\times$ S. macrocephala & $2.3 \mathrm{a}$ & $2.8 \mathrm{c}$ & $1168 \mathrm{a}$ & $436 \mathrm{a}$ \\
\hline Flemingia macrophylla & $2.0 \mathrm{a}$ & $2.9 \mathrm{c}$ & $999 b$ & $351 b$ \\
\hline Gliricidia sepium & $1.5 \mathrm{~b}$ & $2.8 \mathrm{c}$ & $737 \mathrm{e}$ & $260 \mathrm{e}$ \\
\hline Cajanus cajan & $1.7 \mathrm{~b}$ & $3.1 \mathrm{~b}$ & $838 \mathrm{c}$ & $271 d$ \\
\hline Mimosa caesalpiniifolia (leaf) & $1.8 \mathrm{~b}$ & $3.2 \mathrm{a}$ & $917 \mathrm{c}$ & $284 \mathrm{c}$ \\
\hline M. caesalpiniifolia (bark) & $2.0 \mathrm{a}$ & $3.5 \mathrm{a}$ & $993 b$ & $284 \mathrm{c}$ \\
\hline Coefficient of variation (\%) & 2.1 & 16.1 & 2.1 & 18.9 \\
\hline
\end{tabular}

(1)Means followed by equal letters, in the columns, do not differ, by Tukey's test, at $5 \%$ probability. Results presented on a dry matter basis, and standard curves based on purified condensed tannins from each species. 
Table 3. Propelargonidin (PP), prodelphinidin (PD), and procyanidin $(\mathrm{PC})$ of condensed tannin, in six tropical forage legumes.

\begin{tabular}{|c|c|c|c|c|}
\hline \multirow[t]{2}{*}{ Legume } & PP & PD & $\mathrm{PC}$ & \multirow{2}{*}{$\begin{array}{l}\text { PD:PC } \\
\text { ratio }\end{array}$} \\
\hline & \multicolumn{3}{|c|}{----------(\%)---------- } & \\
\hline Cratylia argentea & 44.5 & 30.7 & 24.7 & $30: 25$ \\
\hline $\begin{array}{l}\text { Stylosanthes capitata } \mathrm{x} \\
\text { S. macrocephala }\end{array}$ & 10.7 & 7.1 & 82.1 & 10:80 \\
\hline Flemingia macrophylla & ND & 64.1 & 35.3 & $65: 35$ \\
\hline Gliricidia sepium & ND & 39.8 & 60.2 & $40: 60$ \\
\hline Cajanus cajan & ND & 40.3 & 59.7 & $40: 60$ \\
\hline Mimosa caesalpiniifolia (leaf) & ND & 52.8 & 47.2 & $52: 48$ \\
\hline M. caesalpiniifolia (bark) & ND & 40.0 & 60.0 & $40: 60$ \\
\hline
\end{tabular}

ND, nondetected.

including chemical structure, may play an important role to explain results as well.

Propelargonidin (PP) was detected in C. argentea and stylo; however, PP concentration was 4.2 times greater in $C$. argentea (Table 3 ). The proportion of prodelphinidin (PD) varied from 7.1, in stylo, to 64.1, in F. macrophylla. The two most common CT found in forages are procyanidin (PC) and PD, which have two and three hydroxyls in the B-ring of the flavan-3-ol unit, respectively (Klongsiriwet et al., 2015). A greater hydroxyl number in PD results in a greater biological activity for this compound (Ayres et al., 1997), both reflecting the benefits for the animal (Iqbal et al., 2002; Patra \& Saxena, 2011) and the adverse effects related to the reduction of DM intake, and the reduction of fiber and protein digestion (Guimarães-Beelen et al., 2006). This might be explained by the concentration of this monomer in the plant, and by its relationship with procyanidin, considering that in some plants these compounds form mixtures which are difficult to separate (Klongsiriwet et al., 2015). According to Molan et al. (2003), the PD:PC ratio affects the biological activity. These authors compared CT extracts of Lotus pedunculatus and Onobrychis viciifolia with a PD:PC ratio of 70:30 and 77:23, respectively, with the extract of Lotus corniculatus with a PD:PC ratio of 27:73. They correlated greater activity in the extract with greater proportion of prodelphinidin, using these extracts on larvae of Trichostrongylus colubriformis. As shown in the present research, the condensed tannin bioactivity varies with plant species and plant fraction, chemical structure, and concentration, corroborating other results from the literature.

\section{Conclusions}

1. Concentrations of extractable condensed tannin, protein-bound condensed tannin, total condensed tannin, and protein precipitate by phenols differ among species, but no differences are found for fiber-bound condensed tannin in among the six studied forage legumes.

2. Concentration of protein-bound condensed tannin is higher in Flemingia macrophylla, and the total condensed tannin concentration varies from nondetected values in Cratylia argentea to the highest concentration in Mimosa caesalpiniifolia leaves.

3. The studied legumes show widely differing PPP concentrations, and their greatest levels occur in $M$. caesalpiniifolia leaves; however, C. argentea and Gliricidia sepium show no protein precipitate by phenols; no differences are observed for polymerization degree in stylo, F. macrophylla, and M. caesalpiniifolia.

4. If offered as sole feeds in ruminant diets, the leaves of Stylosanthes capitata x Stylosanthes macrocephala (stylo), Cajanus cajan, and G. sepium should be beneficial as condensed tannin sources, since all of which contain between 20 and $50 \mathrm{~g} \mathrm{~kg}^{-1}$ total condensed tannin.

5. No differences are observed for polymerization degreeinstylo, F. macrophylla, and M.caesalpiniifolia, and the ratio of prodelphinidin:procyanidin varies from 10:80 (stylo) to 65:35 (F. macrophylla); propelargonidin was only determined in $C$. argentea.

\section{Acknowledgments}

To Fundação de Amparo à Pesquisa do Estado do Rio de Janeiro (Faperj), to Conselho Nacional de Desenvolvimento Científico e Tecnológico (CNPq), for financial support and schlolarships granted.

\section{References}

ANDERSSON, M.S.; SCHULTZE-KRAFT, R.; PETERS, M.; HINCAPIÉ, B.; LASCANO, C.E. Morphological, agronomic and forage quality diversity of the Flemingia macrophylla world collection. Field Crops Research, v.96, p.387-406, 2006. DOI: 10.1016/j.fcr.2005.09.002. 
ANIMUT, G.; PUCHULA, R.; GOETSCH, A.L.; PATRA, A.K.; SAHLU, T.; VAREL, V.H.; WELLS, J. Methane emission by goats consuming different sources of condensed tannins. Animal Feed Science and Technology, v.144, p.228-241, 2008. DOI: 10.1016/j. anifeedsci.2007.10.015.

AYRES, M.P.; CLAUSEN, T.P.; MCLEAN JR., S.F.; REDMAN, A.M.; REICHARDT, P.B. Diversity of structure and antihervibore activity in condensed tannins. Ecology, v.78, p.1696-1712, 1997. DOI: 10.1890/0012-9658(1997)078[1696:DOSAAA]2.0.CO;2.

BALOGUN, R.O.; JONES, R.J.; HOLMES, J.H.G. Digestibility of some tropical browse species varying in tannin content. Animal Feed Science and Technology, v.76, p.77-78, 1998. DOI: 10.1016/ S0377-8401(98)00210-7.

GUIMARÃES-BEELEN, P.M.; BERCHIELLI, T.T.; BEELEN, R.; ARAÚJO FILHO, J.; OLIVEIRA, S.G. de. Characterization of condensed tannins from native legumes of the Brazilian northeastern semi-arid. Scientia Agricola, v.63, p.522-528, 2006. DOI: 10.1590/S0103-90162006000600002.

CANO, R.; CARUlla, J.; LASCANO, C.E. Métodos de conservación de muestras de forraje de leguminosas tropicales y su efecto en nivel y en la actividad biológica de los taninos. Pasturas Tropicales, v.16, p.2-7, 1994.

COOPER, C.E.; NAUMANN, H.D.; LAMBERT, B.D.; MUIR, J.P.; KATTES, D.H. Legume protein precipitable phenolic and nutrient concentration responses to defoliation and ontogeny. Journal of Plant Interactions, v.9, p.468-477, 2014. DOI: 10.1080/17429145.2013.860561.

DENTINHO, M.T.P.; BESSA, R.J.B. Effect of tannin source and $\mathrm{pH}$ on stability of tannin-protein and fibre complexes. Revista de Ciências Agrárias, v.39, p.114-121, 2016.

GEA, A.; STRINGANO, E.; BROWN, R.H.; MUELLERHARVEY, I. In situ analysis and structural elucidation of sainfoin (Onobrychis viciifolia) tannins for high-throughput germplasm screening. Journal of Agricultural and Food Chemistry, v.59, p.495-503, 2011. DOI: 10.1021/jf103609p.

GONÇALVES, C. de A.; LELIS, R.C.C.; ABREU, H. dos S. Caracterização físico-química da madeira de sabiá (Mimosa caesalpiniaefolia Benth.). Revista Caatinga, v.23, p.54-62, 2010.

HAGERMAN, A.E.; BUTLER, L.G. Protein precipitation method for the quantitative determination of tannins. Journal of Agricultural and Food Chemistry, v.26, p.809-812, 1978. DOI: 10.1021/jf60218a027.

HUANG, X.D.; LIANG, J.B.; TAN, H.Y.; YAHYA, R.; KHAMSEEKHIEW, B.; HO, Y.W. Molecular weight and protein binding affinity of Leucaena condensed tannins and their effects on in vitro fermentation parameters. Animal Feed Science and Technology, v.159, p.81-87, 2010. DOI: 10.1016/j. anifeedsci.2010.05.008.

IQBAL, Z.; MUFTI, K.A.; KHAN, M.N. Anthelmintic effects of condensed tannins. International Journal of Agriculture \& Biology, v.4, p.438-440, 2002.

KLONGSIRIWET, C.; QUIJADA, J.; WILLIAMS, A.R.; MUELLER-HARVEY, I.; WILLIAMSON, E.M.; HOSTE, H. Synergistic inhibition of Haemonchus contortus exsheathment by flavonoid monomers and condensed tannins. International Journal for Parasitology: Drugs and Drug Resistance, v.5, p.127-134, 2015. DOI: 10.1016/j.ijpddr.2015.06.001.

LAMY, E.; RAWEL, H.; SCHWEIGERT, F.J.; SILVA, F.C. e; FERREIRA, A.; COSTA, A.R.; ANTUNES, C.; ALMEIDA, A.M.; COELHO, A.V.; SALES-BAPTISTA, E. The effect of tannins on Mediterranean ruminant ingestive behavior: The role of the oral cavity. Molecules, v.16, p.2766-2784, 2011. DOI: $10.3390 /$ molecules 16042766 .

LARA, C.E.R.; GARCÍA, J.M.P.; LÓPEZ, J. Influencia del pastoreo en la concentración de fenoles totales y taninos condensados en Gliricidia sepium en el trópico seco. Livestock Research for Rural Development, v.12, p.1-9, 2000.

LIN, Y.M.; LIU, J.W.; XIANG, P.; LIN, P.; DING, Z.H.; STERNBERG, L. da S.L. Tannins and nitrogen dynamics in mangrove leaves at different age and decay stages (Jiulong River Estuary, China). Hydrobiologia, v.583, p.285-295, 2007. DOI: 10.1007/s10750-006-0568-3.

LITTLEFIELD, K.A.; MUELLER, J.P.; MUIR, J.P.; LAMBERT, B.D. Correlation of plant condensed tannin and nitrogen concentrations to white-tailed deer browse preferences in the cross timbers. Texas Journal of Agriculture and Natural Resources, v.24, p.1-7, 2011.

MANE, C.; SOMMERER, N.; YALCIN, T.; CHEYNIER, V.; COLE, R.B.; FULCRAND, H. Assessment of the molecular weight distribution of tannin fractions through MALDI-TOF MS analysis of protein-tannin complexes. Analytical Chemistry, v.79, p.2239-2248, 2007. DOI: 10.1021/ac061685+.

MOLAN, A.L.; MEAGHER, L.P.; SPENCER, P.A.; SIVAKUMARAN, S. Effect of flavan-3-ols on in vitro egg hatching, larval development and viability of infective larvae of Trichostrongylus colubriformis. International Journal for Parasitology, v.33, p.1691-1698, 2003. DOI: 10.1016/S00207519(03)00207-8.

MUELLER-HARVEY, I. Unravelling the conundrum of tannins in animal nutrition and health. Journal of the Science of Food and Agriculture, v.86, p.2010-2037, 2006. DOI: 10.1002/jsfa.2577.

MUETZEL, S.; BECKER, K. Extractability and biological activity of tannins from various tree leaves determined by chemical and biological assays as affected by drying procedure. Animal Feed Science and Technology, v.125, p.139-149, 2006.

MUIR, J.P. The multi-faceted role of condensed tannins in the goat ecosystem. Small Ruminant Research, v.98, p.115-120, 2011. DOI: 10.1016/j.smallrumres.2011.03.028.

MUIR, J.P.; PITMAN, W.D.; DUBEUX JR, J.C.; FOSTER, J.L. The future of warm-season, tropical and subtropical forage legumes in sustainable pastures and rangelands. African Journal of Range \& Forage Science, v.31, p.187-198, 2014. DOI: 10.2989/10220119.2014.884165.

NAUMANN, H.D.; HAGERMAN, A.E.; LAMBERT, B.D.; MUIR, J.P.; TEDESCHI, L.O.; KOTHMANN, M.M. Molecular weight and protein-precipitating ability of condensed tannins from warm-season perennial legumes. Journal of Plant Interactions, v.9, p.212-219, 2014. DOI: 10.1080/17429145.2013.811547. 
NAUMANN, H.D.; LAMBERT, B.D.; ARMSTRONG, S.A.; FONSECA, M.A.; TEDESCHI, L.O.; MUIR, J.P.; ELLERSIECK, M.R. Effect of replacing alfalfa with panicled-tick clover or Sericea lespedeza in corn-alfalfa-based substrates on in vitro ruminal methane production. Journal of Dairy Science, v.98, p.3980-3987, 2015. DOI: 10.3168/jds.2014-8836.

NEPOMUCENO, D. de D.; ALMEIDA, C.C. de C.; CARVALHO, M.G. de; FERNANDES, R.D.; JÚNIOR, F.E.A.C. Classes of secondary metabolites identified in three legume species. Revista Brasileira de Zootecnia, v.42, p.700-705, 2013. DOI: 10.1590/ S1516-35982013001000002.

NOZELLA, E.F. Determinação de taninos em plantas com potencial forrageiro para ruminantes. 2001. 58p. Dissertação (Mestrado) - Universidade de São Paulo, Piracicaba.

PATRA, A.K.; SAXENA, J. Exploitation of dietary tannins to improve rumen metabolism and ruminant nutrition. Journal of the Science of Food and Agriculture, v.91, p.24-37, 2011. DOI: 10.1002/jsfa.4152.

SARTOR NETO, A.; RIBEIRO, E.L. de A.; MIZUBUTI, I.Y.; PEREIRA, E.S.; CUNHA, G.E.; SILVA, L. das D.F. da; BARBOSA, M.A.A. de F.; BUMBIERIS JUNIOR, V.H. Desempenho e características de carcaça de bovinos Nelore confinados recebendo dietas de alto teor de concentrado com diferentes níveis de tanino. Semina: Ciências Agrárias, v.32, p.1179-1190, 2011. DOI: 10.5433/1679-0359.2011v32n3p1179.

STÜRM, C.D.; TIEMANN, T.T.; LASCANO, C.E.; KREUZER, M.; HESS, H.D. Nutrient composition and in vitro ruminal fermentation of tropical legume mixtures with contrasting tannin contents. Animal Feed Science and Technology, v.138, p.29-46, 2007. DOI: 10.1016/j.anifeedsci.2006.11.008.

TERRILL, T.H.; ROWAN, A.M.; DOUGLAS, G.B.; BARRY, T.N. Determination of extractable and bound condensed tannin concentrations in forage plants, protein concentrate meals and cereal grains. Journal of the Science of Food and Agriculture, v.58, p.321-329, 1992. DOI: 10.1002/jsfa.2740580306.

TERRILL, T.H.; WAGHORN, G.C.; WOOLLEY, D.J.; MCNABB, W.C.; BARRY, T.N. Assay and digestion of ${ }^{14} \mathrm{C}$-labelled condensed tannins in the gastrointestinal tract of sheep. British Journal of Nutrition, v.72, p.467-477, 1994. DOI: 10.1079/BJN19940048.

VETELI, T.O.; MATTSON, W.J.; NIEMELÄ, P.; JULKUNENTIITTO, R.; KELLOMÄKI, S.; KUOKKANEN, K.; LAVOLA, A. Do elevated temperature and $\mathrm{CO}_{2}$ generally have counteracting effects on phenolic phytochemistry of boreal trees? Journal of Chemical Ecology, v.33, p.287-296, 2007. DOI: 10.1007/s10886006-9235-4.

WILLIAMS, V.M.; PORTER, L.J.; HEMINGWAY, R.W. Molecular weight profiles of proanthocyanidin polymers. Phytochemistry, v.22, p.569-572, 1983. DOI: 10.1016/00319422(83)83048-9.

WOLFE, R.M.; TERRILL, T.H.; MUIR, J.P. Drying method and origin of standard affect condensed tannin (CT) concentrations in perennial herbaceous legumes using simplified butanol-HCl CT analysis. Journal of the Science of Food and Agriculture, v.88, p.1060-1067, 2008. DOI: 10.1002/jsfa.3188.

Received on April 25, 2017 and accepted on December 11, 2017

Pesq. agropec. bras., Brasília, v.53, n.9, p.1070-1077, Sept. 2018 DOI: 10.1590/S0100-204X2018000900011 